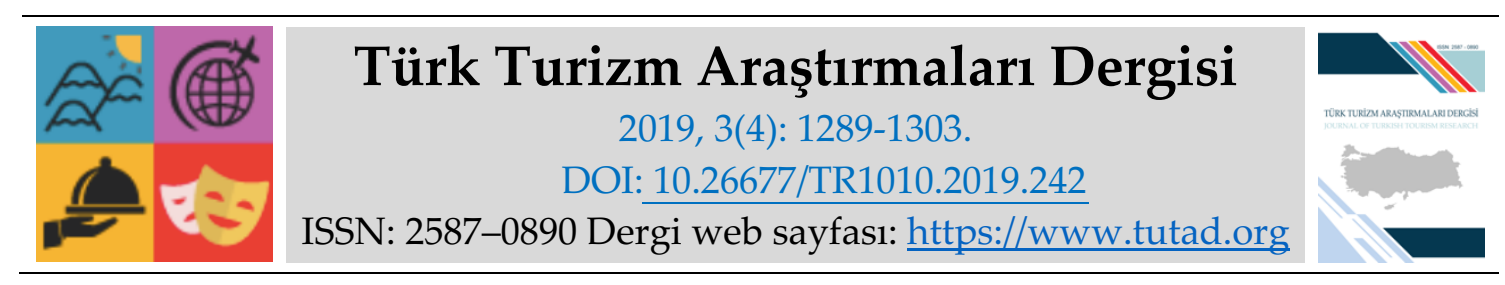

ARASTIRMA MAKALESI

\title{
Turistlerin Alışveriş Davranışlarının Milliyetlere Göre Karşılaştırılması: Marmaris Esnaf Örneği
}

Dr. Öğr. Üyesi Hande Akyurt KURNAZ, Bolu Abant İzzet Baysal Üniversitesi, Turizm Fakültesi, Bolu, e-posta: handekurnaz@ibu.edu.tr ORCID: https://orcid.org/0000-0001-9712-6387

Öz

Türkiye sahip olduğu turizm çekicilikleri sayesinde farklı kültürlerin de turizm açısından cazibe merkezi olmuştur. Doğal ve kültürel özelikleri sebebiyle her kültüre ve her ekonomiye göre tatil imkanlarını bulunmaktadır. Turizm sektörü ekonomiye can veren sektörlerden biri haline gelmiştir. Özellikle alışveriş ve hediyelik ürün imkanlarının çeşitliliği, ekonomik hareketliliği arttıran güçlerden biridir. Bu çalışma, Türkiye'nin önemli turizm potansiyeline sahip olan Marmaris'te gerçekleştirilmiştir. Yapılan çalışmanın amacı, turistlerin alışveriş davranışlarında kültürlerarası bir karşılaştırma yaparak Marmaris esnafı açısından konuyu ele almaktır. Bu bağlamda yapılan çalışmaya uygun olarak esnafa yapılandırılmış görüşme uygulanmıştır. Elde edilen veriler içerik analizi yoluyla analiz edilmiş ve kültürlerarası farklılıklara ve ürün geliştirmeye yönelik önerilerde bulunulmuştur.

Anahtar Kelimeler: Turist, Alışveriş, Milliyet, Marmaris.

Makale Gönderme Tarihi: 29.07.2019

Makale Kabul Tarihi: 07.10.2019

\section{Önerilen Atıf:}

Kurnaz, H. A. (2019). Turistlerin Alışveriş Davranışlarının Milliyetlere Göre Karşılaştııılması: Marmaris Esnaf Örneği, Türk Turizm Araştırmaları Dergisi, 3(4): 1289-1303.

(C) 2019 Türk Turizm Araştırmaları Dergisi. 


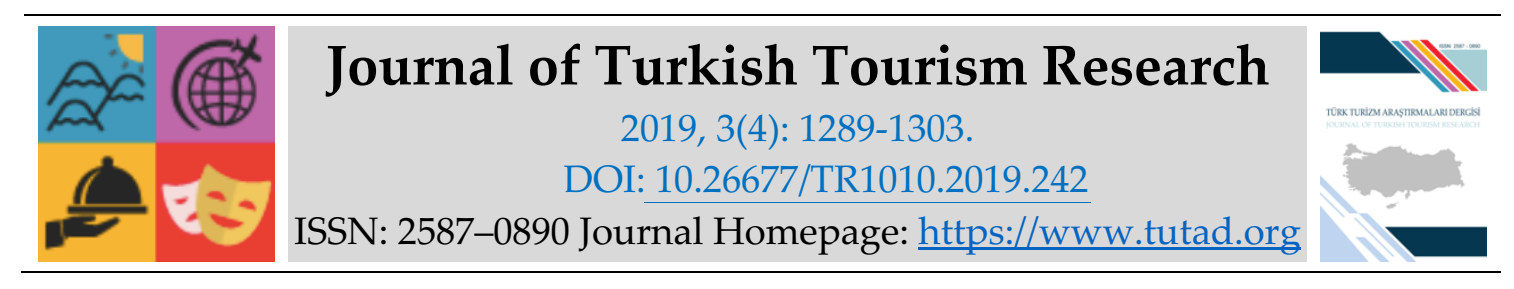

\title{
$\underline{\text { RESEARCH PAPER }}$
}

\section{Comparison of Shopping Behaviors of Tourists According to Nationalities: The Case of Marmaris Tradesman}

Assistant Prof. Dr. Hande Akyurt KURNAZ, Bolu Abant İzzet Baysal University, Faculty of Tourism, Bolu, e-mail: handekurnaz@ibu.edu.tr

ORCID: https://orcid.org/0000-0001-9712-6387

\begin{abstract}
Thanks to tourism attractiveness of different cultures that Turkey has also been the center of attraction in terms of tourism. Due to its natural and cultural characteristics, there are holiday opportunities for every culture and every economy. Tourism sector has become one of the sectors that give life to the economy. Especially, the variety of shopping and gift products is one of the forces that increase economic mobility. This study was performed in Marmaris having significant tourism potential of Turkey. The aim of the study is to make an intercultural comparison of shopping behaviors of tourists and to deal with the issue of Marmaris tradesman. In this context, structured interview was applied to the artisans in accordance with the study. The data obtained were analyzed through content analysis and suggestions were made for intercultural differences and product development.
\end{abstract}

Keywords: Tourist, Shopping, Nationality, Marmaris.

Received: 29.07.2019

Accepted: 07.10.2019

\section{Suggested Citation:}

Kurnaz, H. A. (2019). Comparison of Shopping Behaviors of Tourists According to Nationalities: The Case of Marmaris Tradesman, Journal of Turkish Tourism Research, 3(4): 1289-1303.

(c) 2019 Türk Turizm Araştırmaları Dergisi. 


\section{Gíriş}

Tüketici davranışı üzerine yapılan tüm araştırmaların çoğunda alışveriş motivasyonu kilit unsurlardan biri olarak ortaya çıkmıştır ve bu nedenle bugüne kadar sıkça tartışılmaktadır (Wagner ve Rudolph, 2010). Önceki araştırmalar, çeşitli alışveriş davranış türlerini tanımlasa da alışveriş davranışını gerçekleştiren turistlerin alışveriş beklentilerinin karşılanıp karşılanmadığı ve alışveriş deneyimlerinden memnuniyet düzeylerinin belirlenmesine ihtiyaç duyulmaktadır (Bell ve Lattin, 1998; Tang, vd., 2001; Jones ve Reynolds, 2006).

Turizmin sahip olduğu unsurlar ve etkiler içerisinde alışveriş önemli bir yere sahiptir. Mevcut alışveriş potansiyelinin daha da arttırılması, ürün çeşitliliğine gidilmesi, farklı kültürlerin talep ettikleri ürünlerin belirlenmesi gibi etkiler alışveriş etkinliğinin daha da önemli bir faktör olmasını sağlamakla birlikte bölge ekonomisine de katkıda bulunması muhtemel bir sonuçtur.

Marmaris sahip olduğu doğal ve kültürel özellikleri ile yıl boyunca turizm faaliyetlerini gerçekleştirmenin mümkün olduğu Türkiye'nin temel turizm merkezlerinden biridir. Farklı turizm türlerinin gerçekleştirildiği Marmaris, temel olarak deniz, kum, güneş turizm çeşidi ile bilinmektedir. Ayrıca alışveriş imkanları ve ürün çeşitliliğinin olduğu Marmaris, çeşitli milliyetler tarafından tercih edilen bir destinasyondur. Bu doğrultuda Marmaris'i ziyaret eden turistlerin alışveriş davranışlarının belirlenmesi amacıyla yapılan çalışmada yapılandırılmış görüşme yöntemi uygulanmış olup, Marmaris'te esnaf olan kişilere sorular yöneltilmiştir. Çalışma kapsamında alışveriş sırasında turistlerle birebir iletişim içerisinde olan esnafların dahil edilmesi ve alışveriş sırasında göstermiş oldukları davranışların esnaflar tarafından belirtilmesi çalışmanın önemini oluşturmaktadır. Özellikle alışveriş davranışı ile ilgili çalışmalar incelendiğinde çoğunlukla turistler ile ilgili araştırmaların olduğu, esnafların görüşlerini temel alan araştırmaların yeni çalışılan konular arasında yer aldığı görülmüştür. Bu açıdan yapılan çalışmanın literatürde destekleyici bir şekilde yer alması düşünülmektedir. Ayrıca bu çalışma uygulama yönünden yol gösterici niteliğinde olmaktadır. Farklı milliyetlere yönelik alışveriş davranışlarının açıklanmaya çalışılmasıyla konu ile ilgili hem işletmelere hem de gelecek araştırmalara ışık tutacağı öngörülmektedir. Çalışmanın sonucunda da hem esnaf açısından hem de ürün çeşitliliği açısından çeşitli önerilerde bulunarak katkı sağlanmaya çalışılmıştır.

\section{ALIŞVERIŞ̧ DAVRANIŞI}

Alışveriş, yapılan seyahatlerin ana amaçlarından biri (Kent vd., 1983) ve başlıca turizm faaliyetlerinden biri olarak kabul edilerek alışveriş turizmi adı altında yer almaktadır (Cohen 1995). Özellikle alışveriş olanaklarının bulunduğu alanlar destinasyonlarda turistik cazibe merkezi olarak yer alabilmektedir (Ryan 1991). Ayrıca alışveriş etkinliği aynı zamanda yerel ekonominin gelişmesi ve istihdamı için önemli olup, destinasyonlara gelir yaratarak kalkınmasında bir aracı olmaktadır (Reisinger ve Turner, 2002). Alışveriş hem yerli hem de yabancı turistler için en popüler etkinlik olarak kabul edilmektedir. Alışverişi konumlandırma stratejisi olarak benimseyen pek çok destinasyonla birlikte, alışveriş ürünlerinin gelişimi turizmi teşvik etmek için çok önemlidir (Lehto vd., 2014).

Turizmde meydan gelen alışverişin önemi, alışveriş sırasında turistlerin göstermiş olduğu davranış ve beklentileri hakkında çok az bilgiye sahip olunmasıdır. Bunun temel nedeni turistler alışverişleri esnasında farklı kimlik ve davranışlar içerisine girmektedir. Günlük bir faaliyet olarak alışveriş, toplumsal süreçlere ve sosyal ilişkilere etki eden bir etkinlik olarak karşımıza çıkmaktadır (Miller, 1998). Özellikle kişiler arasında görünmez bir bağ oluşturan alışveriş davranışı sosyal etkileşim yoluyla kazanılır, bağlam ve duruma dayalıdır (Khare, 2011). Önemli bir turizm etkinliği olarak sayılan alışveriş, turistlerin hizmet memnuniyetini belirleyen önemli 
bir faktördür (Kim, 2018). Turistik alışveriş harcamaları toplam seyahat harcamalarının \%30'undan fazlasını oluşturmaktadır ve bu miktar bazen yemek, konaklama, ulaşım ve eğlence amaçlı harcamalardan daha fazladır (Oviedo-Garcia vd., 2016).

Alışverişe verilen önemin giderek artması sonucunda alışverişin kendisi, alışveriş turizmi adı altında bazı destinasyonları ziyaret etmek için ana motivasyon haline gelmiştir (Turner ve Reisinger, 2001). Ayrıca, turist alışverişi, destinasyonlarda çeşitli iş fırsatlarını yaratarak ve esnafın gelirlerini artırarak ekonomik büyümeye önemli bir katkı sağlamasından dolayı, turizm alanındaki araştırmacılar, turist alışveriş davranışları hakkında çeşitli çalışmalar gerçekleştirmiştir (Murphy vd., 2011). Hatta turist faaliyetlerinin hükümet tarafından kontrol altında tutulduğu ülkelerde turistlerin hem genel alışveriş hem de hediyelik eşya alışveriş deneyimini araştıran çalışmaların sayısı oldukça düşük olmasına rağmen popüler konuların başında gelmektedir (Li ve Ryan, 2018). Turist motivasyonlarını ve satın alma davranışlarını daha iyi anlamaya çalıştıkları için alışveriş yapma davranışı giderek daha önemli bir araştırma alanı haline gelmiştir. Özelikle hediyelik eşya konusunda turistik alışveriş üzerine yapılan çalışmalardan ortaya çıkan hediye alımlarından turistlerin davranışlarının farklılaştığı yönünde olmuştur (Gao vd., 2017). Konu ile ilgili bilgilere dayanarak alışveriş davranışı ile ilgili birçok çalışma yapıldığı görülmüştür. Yapılan bu çalışma konusu ile ilgili literatürle paralellik göstermekte ve farklı bir bakış açısı ile konuyu değerlendirmeye çalışmaktadır. Turistlerin satın aldıkları ürünler incelenmiş ve tespit edilmeye çalışılmıştır. Bu yönü ile birtakım çalışmalarla paralellik gösterdiği düşünülmektedir. Yapılan bu araştırma diğer çalışmalardan bir yönü ile farklılık göstermektedir. Elde edilen bulgular, esnaflarla yapılan görüşmeler sonucunda ortaya çıkmıştır.

Timothy (2005) tarafından yapılan araştırmaya göre; turistler farklı amaçlar doğrultusunda alışveriş yapmaktadır. Kimi turistler kendileri için pazarlık yaparak alışveriş yaparken, kimi turistler de hediye almak için alışveriş etkinliğini gerçekleştirmektedir. Hatta bazı turistler alışverişleri sırasında sadece vitrinlere bakarak ürün hakkında karar vermektedir. Uluslararası turistler için, mal ve yerel ürün satın alma süreci genellikle yerel vatandaşlarla belirli bir ilişki biçimini temsil eden ilginç bir sosyal süreçtir. Bir turizm etkinliği olarak alışveriş yapmak, bir seyahat destinasyonunun sahip olduğu etkinlik çeşitleri arasında giderek daha önemli bir rol üstlenmiştir. Alışveriş, turistlerin seyahat ederken sıkça katıldığı bir etkinlik haline gelmiştir. (Jansen-Verbeke, 1991). Turistlerin, seyahat bütçelerinin önemli bir kısmını hediyelik eşyalar ve diğer ürünler için alışveriş yaparak harcadıkları belirlenmiştir (Heung ve Cheng, 2000). Turistler tatilleri sırasında veya sonrasında, giysiler, yiyecekler, lüks eşyalar (Park vd., 2010), el sanatları ürünleri ve bölgeye ait hediyelik eşyalar (Bowen ve Clarke, 2009) dahil olmak üzere çeşitli ürünler satın almaktadır. Alışveriş turistlerin en unutulmaz olumlu ya da olumsuz deneyimlerinden biri olabilmektedir (Swanson ve Timothy, 2012). Ayrıca turistlerin tatil bütçeleri içerisinde harcama kalemlerinin başında da olabilmektedir (Cai vd., 2001). Özellikle bazı şehir turizminin gerçekleştiği destinasyonlarda alışveriş, turistleri çeken önemli bir faktördür (Henderson vd., 2011). Ayrıca destinasyonlarda yer alan sokak pazarları veya pazarlar, genellikle eğlence amaçlı alışverişin gerçekleştirildiği alanlar olmakla birlikte bu tip yerler alışverişe canlılık katmaktadır (Correia ve Kozak, 2016).

\section{BIIR TURIZM DESTINASYONU MARMARIS}

Türkiye sahip olduğu hem kültürel hem de doğal güzellikler neticesinde farklı turizm ürünlerinin bir arada sunulduğu popüler bir turizm merkezidir. Özellikle deniz, kum, güneş turizmi açısından Marmaris, Türkiye'nin önde gelen destinasyonları arasında yerini almıştır. 
Doğal bir liman olan Marmaris, birçok sayıda koy, yat limanları, mavi yolculuk imkanları ile tüm yıl deniz turizmi açısından oldukça popülerdir (Şenol, 2015).

Turizm destinasyonu olan Marmaris'in tarihi antik döneme kadar uzanmaktadır. Marmaris'in eski adı "Physkos" olmakla birlikte Karya dilinde "Doğakenti" anlamını taşımaktadır. Marmaris Kalesi ve müzesi, yat limanları, pazar yerleri, Tarihi Bedesten, Hafza Sultan Kervansarayı gibi birçok kültürel ve doğal güzelliklere sahiptir (https://mugla.ktb.gov.tr/). Sahip olduğu pazarlar ve çarşılar sayesinde alışveriş imkanları açısından oldukça geniş bir ürün yelpazesi bulunmaktadır. Ayrıca farklı milliyetlerden gelen turistlerin beklentilerini karşılayabilmek üzere çeşitli alternatif turizm çeşitleri de mevcuttur.

\section{ARAŞTIRMA YÖNTEMI}

Araştırmanın amacı turistlerin alışveriş davranışlarında kültürlerarası farklılıkları çeşitli esnafın görüşleri doğrultusunda belirlemektir. Çalışma Marmaris destinasyonunda yapılmış olup, yerel halktan esnafın dahil edilmesi ve ürün çeşitlilikleri konusunda bilgi sahibi olunması açısından çalışmanın önemli olduğu düşünülmektedir. Yapılan çalışmada araştırmacının alana yakın olması, turist profilinin farklılık göstermesi ve destinasyonu konu alan alışveriş davranışı ile ilgili yapılan çalı̧̧maların azınlıkta olması sebebiyle çalışmanın veri toplama sahası Marmaris seçilmiştir. Yapılan bu araştırma kapsamında nitel araştırma yöntemlerinden biri olan görüşme veri toplama metodundan faydalanılmıştır. Görüşme türleri içerisinden yapılandırılmış görüşme yöntemi tercih edilmiş olup, sezon yoğunluğu ve zaman kısitlılığı olması sebebiyle 5-10 dk. arasında görüşmeler gerçekleştirilmiştir. Araştırmanın evreni Marmaris'te yer alan esnaflardır. Örneklem belirlemede ise ölçüt örneklem kullanılmıştır. Bu bağlamda 15 yıl ve üstü meslek deneyimine sahip olanlar görüşmeye alınmıştır. Meslek deneyimi temel belirleyici etken olmuştur. Turistlerin çoğunlukla alışveriş yaptığı dükkanlar tercih edilmiştir. Araştırmayı kabul eden toplam 22 kişi ile yüz yüze bir şekilde görüşmeler gerçekleştirilmiştir. Yapılandırılmış görüşme soru formu toplam 6 sorudan oluşmaktadır. Görüşme formu soruları uluslararası literatür (MacCannell, 2002, Snepenger vd., 2003, Moscardo, 2004; Akyurt Kurnaz, 2018) çalışmalarından faydalanılarak oluşturulmuş olup, uzman görüşü ile desteklenmiştir. Uzman inceleme yardımıyla geçerlilik ve güvenirlik sağlanmıştır. Yapılan görüşmeler 2019 yılında, Mart ve Haziran ayları arasında yapılmıştır. İçerik analizi yardımıyla elde edilen görüşme bulguları yorumlanmıştır. Katılımcılar ile yapılan görüşmeler birebir not alınarak gerçekleştirilmiştir. Görüşmeyi kabul eden ve araştırmaya dahil olan katılımcılar K1'den K22'ye kadar kodlanmıştır. Görüşme verilerinde tekrara ulaştıktan sonra araştırma sonlandırılmıştır. Araştırmaya katılan kişilerin kendilerini tanımlayıcı bilgilerine de yer verilmiştir.

\section{ARAŞTIRMA BULGULARI}

Araştırmada görüşlerini paylaşan katılımcılara ait tanımlayıcı bilgiler frekans analizi ile yorumlanmış olup Tablo 1'de yer almıştır.

Araştırma kapsamında 16 erkek (\%72) ve 6 (\%28) kadın katılımcı ile görüşülmüştür. Yaş grupları incelendiğinde 40-49 yaşları arasında 13 (\%59), 50-59 yaş grubunda 8 (37) ve 60 yaş ve üzeri yaş aralığında ise 1 kişi (\%4) bulunmaktadır. Katılımcıların çoğu İngilizce bildiklerini söylemiştir. Eğitim durumları incelendiğinde ise ilköğretim 7 (\%31), lise 12 (\%55), lisans eğitimini bitirenler ise 3 (\%14) kişidir. Araştırmanın örneklemini belirleyen kişilerin çalışma yılları olmuştur. Buna göre 15-24 yılları arasında 13 (\%59), 25-34 yılları arasında 8 (\%37) ve 35-44 yılları arasında deneyime sahip olan $1(\% 4)$ katılımcı yer almıştır. 
Tablo 1. Katılımcılara Ait Tanımlayıcı Bilgiler

\begin{tabular}{|c|c|c|c|c|c|}
\hline Kişi & Cinsiyet & Yaş & Bilinen Diller & $\begin{array}{l}\text { Eğitim } \\
\text { Durumu }\end{array}$ & $\begin{array}{l}\text { Deneyim } \\
\text { (yil) }\end{array}$ \\
\hline K1 & Erkek & 45 & $\begin{array}{l}\text { Orta Seviye } \\
\text { Rusça -İngilizce }\end{array}$ & Lise & 18 \\
\hline K2 & Erkek & 41 & Almanca-İngilizce-Felemenkçe & Lisans & 25 \\
\hline K3 & Erkek & 42 & İngilizce-Rusça & Lise & 16 \\
\hline K4 & Erkek & 40 & İngilizce & Lise & 15 \\
\hline K5 & Kadın & 41 & İngilizce & Lise & 17 \\
\hline K6 & Erkek & 45 & İngilizce & Lise & 17 \\
\hline K7 & Erkek & 40 & İngilizce & Lisans & 20 \\
\hline K8 & Kadın & 48 & İngilizce & Lise & 25 \\
\hline K9 & Erkek & 52 & İngilizce-Rusça & İlköğretim & 20 \\
\hline K10 & Kadın & 55 & İngilizce-Fince-Almanca & İlköğretim & 28 \\
\hline K11 & Erkek & 58 & $\begin{array}{l}\text { İngilizce-Almanca-Rusça-Felemenkçe- } \\
\text { Kırgızca-Norveçce-İsveçce-Danca }\end{array}$ & Lise & 26 \\
\hline K12 & Erkek & 50 & Orta Seviye İngilizce-Rusça & Lisans & 28 \\
\hline K13 & Erkek & 49 & Orta Seviye İngilizce & Lise & 20 \\
\hline K14 & Erkek & 59 & Arapça & İlköğretim & 41 \\
\hline K15 & Erkek & 45 & İngilizce-Arapça & İlköğretim & 20 \\
\hline K16 & Kadın & 60 & İngilizce & Lise & 25 \\
\hline K17 & Erkek & 45 & $\begin{array}{l}\text { İngilizce-Farsça-Arapça-Rusça- } \\
\text { Almanca- }\end{array}$ & İlköğretim & 15 \\
\hline K18 & Erkek & 40 & İngilizce-Rusça-Arapça & Lise & 17 \\
\hline K19 & Kadın & 50 & İngilizce & İlköğretim & 20 \\
\hline K20 & Erkek & 43 & İngilizce-Rusça & Lise & 17 \\
\hline K21 & Kadın & 55 & İngilizce & İlköğretim & 26 \\
\hline K22 & Erkek & 57 & İngilizce-Almanca & Lise & 34 \\
\hline
\end{tabular}

İşletmeleri tanıma amaçlı üç özellik sorulmuştur. Bunlardan ilki işletmenin türü ikincisi işletmenin faaliyet gösterdiği aylar ve son olarak ise satılan ürünlere dair bilgilerdir. Esnaflık yaptıkları işletme türlerine göre kuyumcu $\% 37$, tekstil \%18, aktar \%4, hediyelik eşya \%14, çantacı \%9, ayakkabıcı \%14 ve halı-kilim \%4 şeklinde çalışma alanları yer almıştır. İşletmelerin faaliyet süreleri incelendiğinde 12 ay boyunca açık olan 8 (\%36), sezon boyunca açık olan 14 (\%64) işletme bulunmaktadır. Marmaris'in sahip olduğu deniz, kum, güneş turizmi düşünüldüğünde sezon boyunca işletmelerin açık olması beklenen bir sonuçtur. İşletmede satılan ürünler sorulduğunda ise işletmenin türüne uygun bir ürün yelpazesi olduğu görülmüştür. Araştırmaya katılan 14 işletme (\%64) ürünleri hakkında detaylı bilgi verirken 8 işletme (\%36) ise genel bir cevap vermiştir. 
Tablo 2. İşletmeye Ait Tanımlayııı Bilgiler

\begin{tabular}{|c|c|c|c|}
\hline Kişi & İşletme Türü & Faaliyet Zamanı & Satılan Ürünler \\
\hline K1 & Kuyumcu & Sezon boyunca & Karı yüksek büyük taşlı ve parıltılı takılar \\
\hline K2 & Kuyumcu & Sezon boyunca & Takı \\
\hline K3 & Tekstil & $\begin{array}{l}12 \text { ay boyunca } \\
\text { açlk }\end{array}$ & Giyim ürünü \\
\hline K4 & Aktar & Sezon boyunca & $\begin{array}{l}\text { Saç bakımında kullanılan yağlar, cilt } \\
\text { bakımında kullanılan yağlar, yemeklik yağlar } \\
\text { ve baharatlar }\end{array}$ \\
\hline K5 & Tekstil & Sezon boyunca & Orijinale yakın olmakla birlikte giyim ürünü \\
\hline K6 & Kuyumcu & $\begin{array}{l}12 \text { ay boyunca } \\
\text { açlk }\end{array}$ & Takı, nazarlık, saat \\
\hline K7 & Kuyumcu & $\begin{array}{l}12 \text { ay boyunca } \\
\text { açlk }\end{array}$ & Takı \\
\hline K8 & Hediyelik Eşya & Sezon boyunca & $\begin{array}{l}\text { Magnet, Marmaris yazılı resim, lokum bileklik } \\
\text { ve kolye, tablo, bayrak, harita ve Türk çayı }\end{array}$ \\
\hline K9 & Tekstil & $\begin{array}{l}12 \text { ay boyunca } \\
\text { açik }\end{array}$ & İmitasyon giyim ürünleri \\
\hline K10 & Tekstil & Sezon boyunca & Giyim ürünü \\
\hline K11 & Kuyumcu & Sezon boyunca & Takı \\
\hline K12 & Kuyumcu & $\begin{array}{l}12 \text { ay boyunca } \\
\text { açık }\end{array}$ & $\begin{array}{l}\text { Gümüş üzerine altın kaplama kolye, bileklik, } \\
\text { küpe, yüzük, halhal, kişiye özel tasarım } \\
\text { hediyelik takılar, doğal taştan takılar ve en son } \\
\text { trend ürünler }\end{array}$ \\
\hline K13 & Çantacı & Sezon boyunca & İmitasyon çanta \\
\hline K14 & Ayakkabicı & $\begin{array}{l}12 \text { ay boyunca } \\
\text { açlk }\end{array}$ & Suni deri ürünler \\
\hline K15 & Ayakkabicı & $\begin{array}{l}12 \text { ay boyunca } \\
\text { açlk }\end{array}$ & Deri sandalet \\
\hline K16 & Hediyelik Eşya & Sezon boyunca & Magnet, takı ürünleri ve süs eşyaları \\
\hline K17 & Çantacı & Sezon boyunca & Suni ve gerçek deri çantalar satıyoruz \\
\hline K18 & Kuyumcu & Sezon boyunca & Bol taşlı ve pahalı takılar \\
\hline K19 & Ayakkabıcı & Sezon boyunca & Terlik, sandalet, ayakkabı \\
\hline K20 & Hediyelik Eşya & Sezon boyunca & $\begin{array}{l}\text { Marmaris yazılı eşyalar, çini, tütsü, anahtarlık } \\
\text { ve magnet }\end{array}$ \\
\hline K21 & Halı ve Kilim & $\begin{array}{l}12 \text { ay boyunca } \\
\text { açlk }\end{array}$ & Halı ve kilim türleri \\
\hline K22 & Kuyumcu & Sezon boyunca & Kolye ve kişiye özel tasarımlar \\
\hline
\end{tabular}

Katılımcılara bu mesleği tercih nedenleri sorulduğunda çoğunlukta olan cevap baba mesleği şeklinde olduğu görülmüştür. "Baba mesleği" diyen 10 (\%45), "giderek gelişen bir sektör ve ürün gelişimi konusunda oldukça önü açıktır" ş̧eklinde görüşlerini belirten 2 (\%9), "hediyelik eşyaların turistler üzerinde etkisi vardır" olarak görüşünü paylaşan 1 (\%4), "maddi yönden yeterli" 3 (\%14), "Marmaris'te eksik olduğunu görüp denemeye karar verdik" şeklinde cevap veren 1 (\%4), "esnaflı̆̆ sevdiğinden" bu mesleği yaptığını söyleyen 1 (\%4), "merak" unsurunun etkili olduğu 2 (\%9), "hobi" olarak mesleği gerçekleştiren 1 (\%4) ve "kadın olmasından dolayı kadınlara hitap eden bir meslek olduğundan" $1(\% 4)$ kişi şeklinde katılımcıların görüşleri alınmıştır. 
Tablo 3. Bu Mesleği Tercih Nedeni

\begin{tabular}{|c|c|c|}
\hline Tema & Kod & Iffade \\
\hline \multirow{9}{*}{ Marmaris } & \multirow{9}{*}{$\begin{array}{l}\text { Mesleği tercih etme } \\
\text { nedeni }\end{array}$} & $\begin{array}{l}\text { K1, K3, K6, K7, K8, K9, K10, K12, K13, K21; Baba } \\
\text { mesleği }\end{array}$ \\
\hline & & K2, K5; Ürün gelişimi, gelişen sektör \\
\hline & & $\begin{array}{l}\text { K4; Marmaris turistlik bir bölge olduğu için hediyelik } \\
\text { eşyaların turistler üzerinde olan etkisi }\end{array}$ \\
\hline & & K11, K17, K22; Maddi yönden karşılıyor \\
\hline & & K14; Eksik olduğunu gördük \\
\hline & & K15; Esnaflı̆̆1 sevmek \\
\hline & & K16, K20; Merak \\
\hline & & K18; Hobi \\
\hline & & $\begin{array}{l}\text { K19; Kadın olduğum için kadınlara hitap eden bir } \\
\text { meslek }\end{array}$ \\
\hline
\end{tabular}

Tablo 4. Hitap Edilen Milliyet

\begin{tabular}{|l|l|}
\hline Kişi & Milliyet \\
\hline K1 & Genellikle yerli turist ve Arap \\
\hline K2 & Arap ve Rus \\
\hline K3 & \%90 İngiliz, İskandinav, Alman, Hollanda \\
\hline K4 & Rus, İngiliz, Fransız \\
\hline K5 & Marmaris'e gelen bütün milliyet \\
\hline K6 & Rus, İngiliz, Arap \\
\hline K7 & Rus \\
\hline K8 & Alman ve Rus \\
\hline K9 & Marmaris'e gelen bütün milliyet \\
\hline K10 & Arap \\
\hline K11 & İngiliz ve Rus \\
\hline K13 & Yerli müşteri başta olmak üzere, Rus, Hollandal,, İngiliz, Rodos (Yunan) ve Arap \\
\hline K14 & Rus, İngiliz, Arap \\
\hline K15 & Rus, Ukrayna, Türk, İngiliz, Alman \\
\hline K16 & Rus ve İngiliz \\
\hline K17 & İngiliz, Türk, Rus, Hollandalı \\
\hline K18 & Rus, İngiliz, Alman ve Hollandalı \\
\hline K19 & Marmaris'e gelen bütün milliyet \\
\hline K20 & Rus, İngiliz ve Alman \\
\hline K21 & Türk, Alman ve Arap \\
\hline K22 & İngiliz ve Rus \\
\hline
\end{tabular}

İşletmenin turist profili incelendiğinde "Hangi milliyet sizden alışveriş yapıyor?" sorusuna genellikle işletmelerin birden fazla milliyete cevap verdikleri görülmüştür. Araştırmaya katılan 22 katılımcidan sadece ikisi tek milliyete hitap etmektedir. Kuyumcu olan K7 (\%4), Rus ve tekstil ürünleri satan K10 (\%4) Arap pazarına ürünlerini sunmaktadır. Bunların haricinde 17 katılımcı (\%77) Rus pazarına ürünlerini satmaktadır. Kendilerinde İngilizlerin alışveriş yaptığını belirten 16 katılımcı bulunmaktadır. Bu bilgiler doğrultusunda Marmaris sahip olduğu hem doğal hem 
de kültürel turistik merkezler nedeniyle her milliyetten (Avrupa ve Ortadoğu) turist çekmektedir.

Tablo 5. Milliyetlere ve İşletme Türlerine Göre Satın Alınan Ürünler

\begin{tabular}{|c|c|c|}
\hline Tema & Kod & Ifade \\
\hline \multirow{9}{*}{ Milliyet } & \multirow{9}{*}{ Ürün } & $\begin{array}{l}\text { K1 (Kuyumcu); Araplar bilezik ve büyük taşlı yüzükler, İngilizler, } \\
\text { Ruslar ve Almanlar kolye; yerli turist altın çșitlerini almaktadır. }\end{array}$ \\
\hline & & $\begin{array}{l}\text { K2 (Kuyumcu); Araplar ve Ruslar, Marmaris'i hatırlatan ürünler } \\
\text { tercih etmektedir. }\end{array}$ \\
\hline & & K4 (Aktar); Ruslar fiyatı ucuz olan ürünleri tercih etmektedir. \\
\hline & & $\begin{array}{l}\text { K5 (Tekstil); Türkler kilim tarzı ürünleri seçerken, yabancılar ev } \\
\text { tekstiline ait ürünleri tercih etmektedir. }\end{array}$ \\
\hline & & $\begin{array}{l}\text { K8 (Hediyelik Eşya); Yöresel tatları sevmektedirler. Lokum tercih } \\
\text { edilmektedir. }\end{array}$ \\
\hline & & $\begin{array}{l}\text { K9 (Tekstil); İskandinavlar, montlar ve kışlık giysilerin yanında } \\
\text { tatilleri boyunca giyebilecekleri elbiseler, tunikler, tişörtler, şortlar; } \\
\text { Ruslar, tunik tarzı giysiler, tişörtler, kotlar ve şık ipekli elbiseler; } \\
\text { Hollandalılar, kot, tişört ve gömlek; İngilizler ise sweatshirt ağırlıklı } \\
\text { alışveriş yapmaktadır. }\end{array}$ \\
\hline & & $\begin{array}{l}\text { K11 (Kuyumcu); bileklik ve kolye, Ruslar; büyük taşlı yüzükler ise } \\
\text { İngilizler tarafından tercih edilmektedir. }\end{array}$ \\
\hline & & K15 (Ayakkabıc1); İngilizler daha kaliteli ürün aramaktadır. \\
\hline & & $\begin{array}{l}\text { K17 (Çantacı); Ruslar, deri çanta talep ederken; İngilizler marka } \\
\text { ürünleri sevdiğinden logo olmasına dikkat etmektedir. }\end{array}$ \\
\hline
\end{tabular}

Tablo 5 doğrultusunda soruya açıklayıcı bir biçimde cevap veren katılımcıların yanıtları incelenmiştir. Bu bağlamda işletme türlerine ve milliyetlere göre satın alınan ürünler çeşitlilik göstermektedir. İngilizlere göre kalite ve marka önemli iken, Ruslar için önemli olan ürünün gösterişli ve fiyatının uygun olmasıdır. Almanlar ve Ruslar yöresel tatları tercih eden milliyet olarak karşımıza çıkmakla birlikte lokum satın aldıkları ürünler arasında yer almaktadır. Kuzey ülkelerinin mevsim olarak soğuk olmasından dolayı fiyat uygunluğu açısından İskandinavlar kışlık giyecek türünü tercih etmektedir. Araplar ise çoğunlukla kuyum ve tekstil alışverişi yapmaktadır.

Tablo 6. Milliyetlere Göre Alışveriş Farklılıkları

\begin{tabular}{|c|c|c|}
\hline Tema & Kod & İfade \\
\hline \multirow{3}{*}{$\begin{array}{l}\text { Milliyet } \\
\text { Çeşitleri }\end{array}$} & \multirow{3}{*}{$\begin{array}{l}\text { Alışveriş } \\
\text { Özellikleri }\end{array}$} & $\begin{array}{l}\text { K1; Araplar, her gördüğünü alma özelliği olan kişilerdir. } \\
\text { "Ingilizler Ruslar ve Almanlar ise pazarlık yapmayı çok seven } \\
\text { milliyetlerdir. Yerli turistler altının fiyatın bildikleri için } \\
\text { bilinçli bir şekilde gelmektedir." }\end{array}$ \\
\hline & & $\begin{array}{l}\text { K3; İngilizlerin alım gücü yüksek ve parası değerli } \\
\text { olduğu için alışverişi severler. Araplar zengin bir millet } \\
\text { olup pazarlık yapmayı severler. "O kadar iyiler ki artık } \\
\text { satmasak da olur diyoruz." Ruslar soğuk insanlardır. } \\
\text { "Hiçbir şey demeden dükkana girer ve hiçbir şey demeden } \\
\text { çıkarlar. Teşekkür bile etmeden çıkarlar." }\end{array}$ \\
\hline & & $\begin{array}{l}\text { K11; Milliyetin farklı olması alışverişi de etkilemektedir. } \\
\text { Alışveriş yaparken turistler; kur farkına çok dikkat }\end{array}$ \\
\hline
\end{tabular}


etmektedir. "Araplar daha çok altın ve daha pahalı taşlı şeyler alırken, Ruslar daha dikkatli harcamalar yapıyorlar."

K13; "Yerli müşteri pazarlık yapmayı sever, özellikle aynı milletten olduğumuzu vurgulayarak fiyatlar indirmeye çalışmaktadır. Hollandalılar orta yolu bulmaya çalışır ve biraz indirimle genelde memnun olmaktadır. Ruslar fiyatı en dibe çekmeye çalışan millettir, pazarlik konusunda sinırlar yoktur. Ingilizler pazarlik yapmaz, fiyatın sorar ona da uyuyorsa direkt alır. Rodoslular beğendiyse fiyatını önemsemeden direkt alır. Araplar ürünü kötüleyerek indirim yaptırmaya çalışırlar, genelde dükkandan kovarım."

K14; "Ruslar, mutlaka üzerlerinde deneme yaparlar ve çok zaman geçirirler ve enerji tükettirirler. Ürünün kendilerine yakışmadığım düşündüklerinde, ne kadar uzun süreli mağazada kalırlarsa kalsınlar, tek bir kelime bile etmeden hatta sinirlenerek çıkıp giderler. Beğendiklerinde ise mutlaka almak için uğraşırlar. Maksimum 2 veya 3 parça alışveriş yaparlar. Her mağazayı araştırırlar. Her mağazaya mutlaka girip çıkarlar. Ama alışveriş yapacakları anlamına gelmez. Ürünün şık olması esastır.

İngilizler, alışveriş yaparken, toplu alışverişi severler. Bütün ürünlerden almak isterler. Logoları büyük ürünleri tercih ederler. Ürün kalitesinin önemi yoktur. Ucuz al, kullan, at ve yenisini yine ucuz al düşüncesindedirler.

Finliler, çok nadir pazarlı yaparlar. Eğer satıcıyı daha önceden tanıyorlar ise güven duygusu hâkimdir. Kendi dillerinin konuşulduğunu duymak çok hoşlarma gider. Kalite ve uzun süreli kullanıma uygun ürünler tercih ederler. Genelde moda olan ürünleri tercih ederler.

Almanlar, çok dediğim dediktirler. Kafalarındaki resme uymazsa kesinlikle alışveriş yapmazlar. Gerçekten beğenmeleri gerekir. Kalite onlar için esastır. Ĕ̆er ürün kaliteli ise mutlaka satın almak isterler ve o ürünü uzun süreli kullanmak isterler. Eğer istedikleri kaliteyi bulurlar ise, mutlaka tekrar için geri dönerler.

Araplar, o sezon hangi ürünün moda olduğu nadiren önemlidir. Gözlerinin gördü̆̆̈̈ ve beğendiği her ürünü almak isterler. Sikı pazarlik yaparlar."

K17; "Kesinlikle etkiliyor. Örneğin: Bazıları kültürü gereği çok renkli ve süslü bazıları da hatıra amacıyla ürünleri satın alıyorlar. Ruslar, genellikle kaba konuşmalarna maruz kahyoruz konuşma şekilleri genelde kavga ediyor gibi ve çok pazarlık yapıyorlar. Ingilizler, genelde pazarlık yapmıyor, güzellik ve el emeği eşyalara yöneliyor. Ruslara göre daha kibar ve güler yüzlülerdir."

K18; "En iyi alı̧̧erişi İngilizler yapıyor. Ruslar çok pazarlık yapıyor. Araplar yar yarıya kadar indirmeye çalışıyor. Araplar, 100TL'lik ürüne 50 TL olmaz mı diyor. Türk ve İngiliz hiç olmazsa 85 TL olmaz mı diyor." 
Milliyetlerin sahip oldukları ekonomik güç ve özellikler alışveriş davranışlarını, talep ettikleri ürünleri, pazarlık sürelerini ve stillerini de değiştirmektedir. Şüphesiz kur farkı alışveriş duyarlılığını etkileyen etmenlerin başında gelmektedir. Kişilerin sahip oldukları ekonomik güç, turizmin önemli bir kalemi olan alışverişe de yansımaktadır. Toplumların sahip olduğu temel özellikler alışverişi etkileyen bir diğer faktördür. Örneğin Ruslar, sahip oldukları özellikleri gereği soğuk müşteri tipi şeklinde tanımlanmıştır. Hemen hemen her milliyet alışveriş sırasında mutlaka pazarlık yapmaktadır. Ama bir derecelendirmenin yapılması doğrultusunda, Ruslar ve Araplar pazarlığ pazarlık yapma söz konusu olmamaktadır. İngilizler pazarlık etmeye gerek duymayan millet olarak incelenmekle birlikte bu durumun sahip oldukları ekonomik güç (kur) ile doğru orantılı olduğu söylenebilir.

Tablo 7. Milliyetlere Göre Davranış Kodları

\begin{tabular}{|c|c|c|}
\hline Tema & Kod & Milliyet \\
\hline \multirow{8}{*}{$\begin{array}{l}\text { Alışveriş } \\
\text { Davranışı } \\
\text { Çeşitleri }\end{array}$} & Naziklik & İngiliz \\
\hline & Kabalık & Rus \\
\hline & Pazarlık Yapma & Arap, Rus, Türk \\
\hline & Kaliteye Dikkat Etme & Finlandiyalı, Alman, \\
\hline & Moda & Finlandiyalı \\
\hline & Pahalı Ürün Tercihi & Arap \\
\hline & Beğenme Yeterli & Rodoslu, Arap \\
\hline & Ürün Şıklığ1 & Rus, İngiliz \\
\hline
\end{tabular}

Tablo 7 doğrultusunda araştırmaya katılan esnafların verdikleri bilgiler derlenmiştir. Görüşmeler sırasında en çok konusu geçen naziklik, kabalık, pazarlık yapma, kaliteye dikkat etme, moda, pahalı ürün tercihi, beğenme yeterli ve ürün şıklı̆̆ kodları belirlenmiştir. Turistlerin alışveriş davranışlarında en çok ortaya çıkan kavramlar bu şekilde yer almıştır. Milliyetlere göre bir karşılaştırma yapıldığında ise; nazik bir şekilde alışverişini gerçekleştiren İngilizler, kaba bir davranış şekli gösterme eğiliminde olan Ruslar; pazarlık yapmayı seven Araplar, Ruslar ve Türkler; kaliteye dikkat eden Finlandiyalılar ve Almanlar; moda ürünleri benimseyen Finlandiyalılar; alışverişlerinde pahalı ürünleri tercih eden Araplar; sadece beğenmenin yeterli olduğu bir alışveriş biçimi benimseyen Rodoslular ve Araplar, en son olarak ürünlerin şık olmasına özen gösterenler ise Ruslar ve İngilizler olarak ortaya çıkmıştır. Bu sonuçlar verilen cevaplar doğrultusunda elde edilmiştir.

Araştırmanın verilerinden elde edilen bulgulara göre Marmaris sahip olduğu turizm potansiyeli doğrultusunda genellikle dükkanların sezon boyunca açı olduğu bir destinasyon özelliği göstermiştir. Her milliyetin özelliklerine uygun ürünlerin bulunduğu ve ürün çeşitliliği gösteren alışveriş potansiyeli bulunmaktadır. Özellikle imitasyon ürün satan dükkanların da bulunması, imitasyon ürünlere olan bir talebin olduğunu göstermektedir. Deniz, kum, güneş turizm çeşidi ile anılmasından dolayı, Ruslar ve İngilizler tarafından tercih edilen bir destinasyon olan Marmaris'te; son yıllarda Arap turistler tarafından tercih edilen turizm bölgelerinden biri olmuştur. Park vd., (2010) ve Bowen ve Clarke (2009)'ın çalışmalarına göre incelendiğinde Marmaris'i ziyaret eden turistler giysiler, yiyecekler, lüks takı eşyalar, el sanatları ve bölgeye ait hediyelik eşyalar gibi ürünleri tercih etmişlerdir. Turistlerin alışverişleri sırasında sergilemiş olduğu bazı davranışlar tespit edilmiştir. Aynı davranışı sergilese bile davranış düzeyi milliyetlere göre değiştiği görülmüştür. Örneğin; pazarlık yapma, ürünlere bakıp çıkma, kaliteli 
ürünleri görme isteği, satıcı ile konuşma tarzlarının farklılaşması gibi çeşitli davranış ve davranış düzeyleri meydana gelmiştir. Yapılan araştırmanın bu sonucu ise, Timothy (2005) tarafından çalışma ile ortak özellikler göstermiştir.

\section{SONUÇ}

Uluslararası platformlarda adını duyuran turizm destinasyonları, alışveriş etkinliğini giderek artan bir turizm kaynağı olarak kullanmaktadır ve alışverişi bölgenin kalkınmasında temel desteklerden biri olarak görmektedir (Jansen-Verbeke, 1991). Birçok turist deneyiminin ayrılmaz bir parçası olarak alışveriş, kişilerin seyahat etmelerinin ana nedenlerinden biri olabilmektedir (Dimanche, 2003). Kişiler için tatilleri ya da seyahatleri sahip oldukları kişisel özel boş zamanları olmakla birlikte günlük yaşam ortamlarından ayrıldıkları bir yerde geçirilen bir hayatlarının bir bölümüdür. Özellikle bir kişi turist olduğunda ve tüketici olarak satın alma davranışı gerçekleştirdiğinde, genellikle evdeki normal düzeninden büyük ölçüde farklılık gösteren bir kişiliğe sahip olması muhtemel bir sonuçtur (Kent vd., 1983).

Turizmin önemli bir etkinliği olan alışverişin önemi yaygın olarak bilinmesine ve ekonomiye olan katkılarının farkında olunmasına rağmen, turistlerin alışverişleri sırasında davranış ve beklentileri, tercihleri, davranışlarını etkileyen faktörleri hakkında hala da araştırmalara devam edilmektedir. Özellikle alışverişin temel noktası turistlerin ihtiyaç duyduğu ve arzu ettiği ürünleri geliştirmek ve bu gelişimi sağlamak için önemli bilgi kaynaklarına ulaşmaktır. Bu aşamada alışveriş ile ilgili yapılan çalışmalar giderek önem kazanmaktadır (Littrell vd., 1994). Alışveriş, en eski turizm faaliyetlerinden biridir ve genellikle seyahat bütçelerinin çoğunluğunu oluşturur (Choi vd., 2016; Jin vd., 2017).

Marmaris esnafının görüşleri alınarak gerçekleştirilen bu çalışmada turistlerin alışverişleri sırasında milliyetler arası bir karşılaştırma yapılması amaçlanmıştır. Buna göre, Marmaris'in alışveriş anlamında yoğun olan alanlarında çalışma gerçekleştirilmiştir. Görüşmeyi kabul eden 22 kişi ile çalışma tamamlanmıştır. Yapılandırılmış soru formu kullanılmış olup, ses kaydı alınamamıştır. Ölçüt örnekleme uygulanarak kişilerin mesleki deneyim yılları esas alınmıştır. Çalışmanın önemi esnaftan bilgi alınarak onların deneyimleri doğrultusunda sonuçlara ulaşılmaya çalışılmasıdır. Elde edilen bulgulardan belli sonuçlar elde edilmiştir.

Araştırmaya katılan katılımcıların belirli özellikleri incelendiğinde; genellikle erkek, 40-49 yaş aralığında, İngilizce bilen, lise mezunu ve 15-24 yılları arasında mesleğini gerçekleştiren kişiler olduğu tespit edilmiştir. Bu mesleği tercih nedenleri hakkında ortalama birçoğu babadan gelen bir meslek olduğunu vurgulamıştır. Marmaris'te eksik olan bir meslek ve turistlerin hediyelik eşyalara olan talebinin artması üzerine de mesleği tercih edenler mevcuttur. İşletmelerin müşteri profili incelendiğinde milliyetler açısından çeşitlilik göstermektedir. Farklı milliyetlere hizmet verdikleri görülmüştür. İngilizler açısından ürünlerin markalı ve kaliteli olması, Ruslar için gösterişli ve fiyatı uygun ürünlerin yer alması, Almanlar ve Ruslar'ın yöresel tatlar konusunda duyarlı olması, Arapların kuyum ve tekstile ilgi duyması ve İskandinavların daha çok kış ayları için tekstil ürünleri tercih etmesi, farklı milliyetlerin ürün tercihlerine yönelik örnekleri olmuştur. Alışveriş süreleri içerisinde göstermiş oldukları tipik davranış özelliği pazarlık etmek olarak karşımıza çıkmıştır. Hemen hemen alışveriş yapan her milliyet derecesi farklı olmakla birlikte pazarlık davranışını gerçekleştirmiştir. Alışveriş yapma imkanını etkileyen önemli bir etken olarak da kur farkı yer almıştır. Kur farkının çok olduğu milliyetlerin daha rahat bir şekilde alışveriş yaptıkları belirtilmiştir. Ayrıca çalışmanın bulgularına göre, milliyetlere göre farklılık gösteren bir alışveriş davranışı bulunmaktadır. İşletmeler ürün bazında bile farklı milliyetlere ait turistlerin satın alma sırasında birbirinden farklı davranışlar sergilediğini belirtmiştir. Bu 
bağlamda Tayfun ve Yıldırım'ın 2010 yılında yapmış oldukları çalışma sonuçları ile benzerlik göstermektedir. Ayrıca alışveriş davranışı farklılığı konusunda Eric ve Powers (2013) çalışması ile ortak noktaları yer almaktadır.

Yapılan bu çalışmanın sonuçları doğrultusunda birtakım öneriler yer almaktadır Öncelikle Marmaris, sahip olduğu turizm çekicilikleri sayesinde yeterli bir şekilde ürün çeşitliliğine sahip turistik bir destinasyon özelliği göstermektedir. Varolan turizm ürünlerinin devamlıllğını ve kalıcılığını sağlamak adına kaliteli ürünlerin ortaya çıkarılması gerekmektedir. Babadan gelen meslek anlayışının devam ettirilerek süreklilik sağlanması muhtemeldir. Kaliteli ürünlerin oluşturulmasıyla birlikte belirli bir fiyat politikası izlenerek, pazarlık etme sorununun önüne geçilmesi söz konusu olabilir. Özellikle Arapların çok fazla bir şekilde pazarlık etmeye ilgi duydukları ve bu durumun esnafları da olumsuz bir şekilde etkilediği görüşmelerde belirtilmiştir. Bu durumu önlemek adına pazarlık olmadığını belirten dükkan içerisinde yer alabilecek ilanların olması bir öneri olabilir. Konu ile ilgili bir diğer öneri ise fiyatlarda bir birlik olması durumunda pazarlık anlayışı dengeli bir şekilde devam edebilir. Turistlere göre oluşturulan ürünler şüphesiz, önemli bir turizm çekiciliği oluşturmaktadır. Marmaris'e gelen milliyetlere ve özelliklerine göre ürünlerin bulunması, dikkat ettikleri özelliklerin ürünlerde yer alması gibi fiziksel özellikler alışverişi daha da canlı tutabilir. Yöresel pazarların arttırılması, yöresel tatların daha çok tanıtımının yapılması, yöresel tat olarak sadece lokumun yer almaması gastronomi ve alışveriş turizmi anlamında ürün çeşitliliği sağlayacaktır ve ilgi uyandıracaktır. Özellikle alışveriş turizmi adı altında turların düzenlenmesiyle birlikte daha çok turist sayısına ve gelirine ulaşılması mümkün olabilir.

\section{KAYNAKÇA}

Akyurt Kurnaz, H. (2018). Turistlerin Hediyelik Eşya Satın Alma Davranışlarının Kültürlerarası Boyutları: Marmaris ve Kapadokya Örneği, Yayımlanmamış Doktora Tezi, Adnan Menderes Üniversitesi, Aydın.

Bell, D. R. and Lattin, J. M. (1998). Shopping Behavior and Consumer Preference for Store Price Format: Why ‘Large Basket’ Shoppers Prefer EDLP, Marketing Science, 17(1): 66-88.

Bowen, D. and Clarke, J. (2009). Contemporary Tourist Behaviour: Yourself and Others as Tourists. UK: CABI, Oxfordshire.

Cai, L., Lehto, X.Y. and O'leary, J. (2001). Profiling the U.S.-Bound Chinese Travelers by Purpose of Trip, Journal of Hospitality \& Leisure Marketing, 7(4): 3-16.

Choi, M., Law, R. and Heo, C. Y. (2016). Shopping Destinations and Trust-Tourist Attitudes: Scale Development and Validation, Tourism Management, 54(2016): 490-501.

Cohen, E. (1995). Touristic Craft Ribbon Development in Thailand, Tourism Management, 16 (3): 225-35.

Correia, A. and Kozak, M. (2016). Tourists' Shopping Experiences at Street Markets: Crosscountry Research, Tourism Management, 56(2016): 85-95.

Dimanche, F. (2003). The Louisiana Tax Free Shopping Program for International Visitors: A Case Study, Journal of Travel Research, 41(3): 311-314.

Eric P. J. and Powers, T. L. (2013). Shopping Behaviour and Satisfaction Outcomes, Journal of Marketing Management, 29(13-14): 1609-1630. 
Gao, H., Huang, S. and Brown, G. (2017). The Influence of Face on Chinese Tourists' Gift Purchase Behaviour: The Moderating Role of The Gift Giver-Receiver Relationship, Tourism Management, 62(2017): 97-106.

Henderson, J. C., Chee, L., Mun, C. N. and Lee, C. (2011). Shopping, Tourism and Retailing in Singapore, Managing Leisure, 16(1): 34-68.

Heung, V. C. S. and Cheng, E. (2000). Assessing Tourists' Satisfaction with Shopping in The Hong Kong Special Administrative Region of China, Journal of Travel Research, 38(4): 396-404.

https://mugla.ktb.gov.tr/ [Erişim Tarihi: 03.09.2019].

Jansen-Verbeke, M. (1991). Leisure Shopping: A Magic Concept for The Tourism Industry?, Tourism Management, 12(1): 9-14.

Jin, H., Moscardo, G. and Murphy, L. (2017). Making Sense of Tourist Shopping Research: A Critical Review, Tourism Management, 62(2017): 120-134.

Jones, M. A. and Reynolds, K. E. (2006). The Role of Retailer Interest on Shopping Behavior, Journal of Retailing, 82(2): 115-126.

Kent, W., Shock, P. and Show, R. (1983). Shopping: Tourism's Unsung Hero(ine), Journal of Travel Research, 21(4): 2-4.

Khare, A. (2011). Mall Shopping Behaviour of Indian Small-Town Consumers, Journal of Retailing and Consumer Services, 18(1): 110-118.

Kim, J. H. (2018). Effect of Brand Popularity as an Advertising Cue on Tourists' Shopping Behavior, Journal of Destination Marketing \& Management, 10(2018): 78-86.

Lehto, X. Y., Chen, S. Y. and Silkes, C. (2014). Tourist Shopping Style Preferences, Journal of Vacation Marketing, 20(1): 3-15.

Li, F. and Ryan, C. (2018). Souvenir Shopping Experiences: A Case Study of Chinese Tourists in North Korea, Tourism Management, 64(February): 142-153.

Littrell, M. A., Baizerman, S., Kean, R., Gahring, S., Niemeyer, S., Reilly, R. and Stout, J. A. (1994). Souvenirs and Tourism Styles, Journal of Travel Research, 33(1): 3-11.

MacCannell, D. (2002). Reflections and Reviews: The Ego Factor in Tourism, Journal of Consumer Research, 29(1): 146-151.

Miller, D. (1998). A Theory of Shopping. NY: Cornell University Press.

Moscardo, G. (2004). Shopping as a Destination Attraction: An Empirical Examination of The Role of Shopping in Tourists' Destination Choice and Experience, Journal of Vacation Marketing, 10(4): 294-307.

Murphy, L., Moscardo, G., Benckendorff, P. and Pearce, P. (2011). Evaluating Tourist Satisfaction with The Retail Experience in a Typical Tourist Shopping Village, Journal of Retailing and Consumer Services, 18(4): 302-310.

Oviedo-Garcia, M. A., Vega-Vazquez, M., Castellanos-Verdugo, M. and Reyes-Guizar, L. A. (2016). Tourist Satisfaction and The Souvenir Shopping of Domestic Tourists: Extended Weekends in Spain, Current Issues in Tourism, 19(8): 845-860. 
Park, K. S., Reisinger, Y. and Noh, E. H. (2010). Luxury Shopping in Tourism, International Journal of Tourism Research, 12(2): 164-178

Reisinger, Y. and Turner, L. W. (2002). The Determination of Shopping Satisfaction of Japanese Tourists Visiting Hawaii and the Gold Coast Compared, Journal of Travel Research, 41(2): 167-176.

Ryan, C. (1991). Recreational Tourism: A Social Science Perspective. New York: Routledge Kegan Paul.

Şenol, F. (2015). Türkiye Turizm Coğrafyası ve Dünya Kültürel Mirası. Ankara: Detay Yayıncılık.

Snepenger, D., Murphy, L., O'Connell, R. and Gregg, E. (2003). Tourists and Residents Use of a Shopping Space, Annals of Tourism Research, 30(3): 567-580.

Swanson, K. K. and Timothy, D. J. (2012). Souvenirs: Icons of Meaning, Commercialization and Commoditization, Tourism Management, 33(3): 489-499.

Tang, C. S., Bell, D. R. and Ho, T. H. (2001). Store Choice and Shopping Behavior, California Management Review, 43(2): 56-74.

Tayfun, A. ve Yıldırım, M. (2010). Turistlerin Tüketim Davranışları Kültüre/Milliyete Göre Farklılık Gösterir mi? Alman ve Rus Turistler Üzerine Bir Araştırma, İşletme Araştırmaları Dergisi, 2(2): 43-64.

Timothy, D. (2005). Shopping Tourism, Retailing and Leisure. Clevedon: Channel View Publication. Turner, L. and Reisinger, Y. (2001). Shopping Satisfaction for Domestic Tourists. Journal of Retailing and Consumer Services, 8(1): 15-27.

Wagner, T. and Rudolph, T. (2010). Towards a Hierarchical Theory of Shopping Motivation, Journal of Retailing and Consumer Services, 17(5): 415-429. 